Purposes and criteria in network governance evaluation: How

far does standard evaluation vocabulary takes us?
I8(I) 27-46

(C) The Author(s) 2012 Reprints and permission: sagepub. co.uk/journalsPermissions.nav DOI: I0.1 I77//3563890| I43।02। evi.sagepub.com @SAGE

\title{
Nils Hertting
}

Uppsala University, Sweden

\section{Evert Vedung}

Uppsala University, Sweden

\begin{abstract}
Evaluation and network governance are both among the top- 10 trendy concepts in public policy. But how are they related? In the present article, we ask how public sector interventions guided by a network governance doctrine are to be evaluated. If evaluation means systematic judgment of organization, content, administration, outputs and effects in public policy, then evaluators need concepts and analytical tools to assess these features and communicate their analyses. In the literature, interest in network modes of governance often goes together with a call for a renewed vocabulary for evaluation and policy analysis. In the article, we do not take this to be a fact. Instead we turn it into a question: How relevant and productive are established concepts and tools of evaluation theory for evaluating network governance? More specifically, we address the issues of purposes and merit criteria in evaluation of interventions fashioned according to the network governance doctrine. Though it takes some elaboration, our overall conclusion is that at least some standard evaluation concepts and approaches are still productive in delineating, analysing and prescribing how network governance can be evaluated. There are crucial accountability issues to raise, the goal-achievement criterion is not irrelevant and the meaning of stakeholder evaluation is elucidated when confronted with the ideas of the network governance doctrine.
\end{abstract}

\section{Keywords}

accountability, evaluation theory, goal-achievement criterion, network governance, stakeholder evaluation 


\section{Introduction}

Throughout the world of developed societies, inter-organizational partnerships, joined-up government, collaborative projects, and co-production seem to be becoming increasingly important in framing and implementing public policy ambitions. Often these new organizational tools are interpreted and conceptualized as networks, networking or network governance (Provan and Kenis, 2007; Sørensen and Torfing, 2007a). According to this 'network narrative', operative policies are or should be produced and implemented in horizontal and reciprocal patterns, where hierarchical relations are of limited relevance. In its normative and prescriptive gestalt, the network mode of governance is an institutional innovation for our time (Koppenjan and Klijn, 2004). According to such an argument, many contemporary policy problems would be probed and handled more effectively and more legitimately through network coordination of resources, skills and strategies across formal organizations, policy sectors and jurisdictions.

In the present article, we ask how public sector interventions guided by a network governance doctrine are to be evaluated. When evaluation is defined as systematic judgment of organization, content, processes, outputs and outcomes in public policy, evaluators need analytical tools to organize and communicate their analyses. In an attempt to contribute to the discussion on evaluation in network governance (cf. Koppenjan and Klijn, 2004; Provan and Milward, 2001; Uusikylä and Valovirta, 2007), we ask how relevant and productive some basic conceptual tools of evaluation theory are in evaluating interventions fashioned in the network governance mode. In the literature, interest in and attention to network types of governance often go together with a call for a new vocabulary for evaluation and policy analysis (Fischer, 2003; Haynes, 2008; Sanderson, 2001). Here, we take another turn. By analysing overall purposes and merit criteria in evaluation of network governance interventions, we investigate how far some of the standard tools of evaluation are able to take us. In doing so, we ask what the roles of accountability and development are as overall purposes of evaluation, and what the significances of goal attainment and stakeholder evaluation are as merit criteria for interventions fashioned according to the network governance doctrine. Throughout the article, it is a fundamental argument that the notion of network governance challenges standard evaluation concepts, though it does not necessarily render them irrelevant.

The article is organized as follows. After this introduction, we outline the most fundamental proposition of our argument: evaluation design should follow governance doctrine. There are several reasons, we claim, to build an evaluation on an interpretation of the governance doctrine underlying the evaluated intervention.

In the third part, we define the concept of network governance doctrine. We do so by applying ideal-type methodology. We claim that such an ideal-type rendering of network governance has the potential to reveal the rationale or logic behind central state steering interventions that otherwise would seem incomprehensible or obscure.

In the fourth and fifth parts of the article, we analyse the relevance and applicability of some standard evaluation theory notions for network governance evaluation. Are they universal enough to fit the network governance doctrine? We discuss the distinction between development and accountability purposes in network governance evaluations. Several aspects of these overarching purposes are delineated, and though the distinction remains relevant it is not particularly obvious or intuitive in the context of a network governance doctrine.

In terms of evaluative criteria, we argue that the network literature is sometimes too quick to dismiss the goal attainment criterion. As a matter of fact, we argue that goals and objectives are relevant evaluation criteria from three different perspectives. In a related analysis, we claim that stakeholder evaluation has many and quite disparate meanings in a network context. We show how 
stakeholder evaluation may take a non-deliberative yet holistic, as well as a deliberative yet individualistic orientation.

\section{Type of governance doctrine, type of evaluation}

The fundamental notion of governance doctrine begetting evaluation design is quite simple. Contemporary public policy is associated with several different ideas about governance strategies: results-oriented management (or management by objectives), client-oriented management, and process-oriented management. It seems reasonable that evaluators will relate their evaluation to the specific governance ideas behind or embedded in the intervention system to be evaluated. More specifically, we argue there are several good reasons for evaluators to adjust their evaluation designs to the underlying governance doctrine of the evaluation object; before beginning, they should do some thinking and reflecting on the ideas embedded in the underlying governance doctrine. First, we suppose that the relevance and utility of the evaluation will be maximized - not only among top policymakers but also among operative implementers and stakeholders. Second, it would seem to be easier both to critically assess and improve an intervention if you have knowledge about the 'theory' it rests upon. Third, if evaluation is an important arena in the political process, it gives the evaluation democratic legitimacy if it is adapted to the institutionalized governance doctrine.

By governance doctrine we mean something like a set of ideas consisting of beliefs about problems in administration, implementation and policy processes that are linked to guidelines for practice and action. The beliefs and values sustain this practical action orientation and render advocated governance strategies reasonable or coherent. ${ }^{1}$ Based on the above definition of governance doctrine, we will outline an explication of how problems and solutions are linked together in one specific governance doctrine: the network governance doctrine. To do this, we will adopt ideal-type methodology. ${ }^{2}$

More specifically, our argument could be read as: 1) an empirical hypothesis about how evaluation actually is designed and carried out (Foss Hansen, 2003; Hertting and Vedung, 2009); or 2) a prescriptive recommendation about how evaluation models should be selected and designed. Here, we follow the second line of argument when we try to develop a set of ideas about how interventions following the network governance doctrine should be evaluated, and we ask whether some traditional notions of evaluation theory are valid for such an enterprise.

\section{The network governance doctrine}

Network governance may seem like a contradiction in terms. The term network carries a notion of something spontaneous, open, flat, and protean. Governance, on the other hand, has to do with guidance, coordination or even direction. A growing body of literature, however, maintains that the rationale of some contemporary public interventions is best interpreted in terms of network governance (Provan and Kenis, 2007; Sørensen and Torfing, 2007a), network management (Kickert et al., 1997; O’Toole et al., 1997), or meta-governance (Klijn and Edelenbos, 2007; Sørensen and Torfing, 2007b).

First, we try to show why central state actors increasingly ask for organized relations across vertical pillars of the public sector. Second, we outline how, according to the ideal-type notion of network governance, such inter-sectoral relations may be organized by the affected actors themselves, and why such horizontal self-organization might be attractive to central state actors and how these actors may use several different policy instruments to promote and assist the development of 
governance networks. Based on these theoretical arguments, we will finally refine and distill the ideal-type definition.

\section{The governance problem: Substantive and institutional complexity creates a need for coordination}

According to our ideal-type, network governance doctrine complexity is the major root of performance inefficiency, illegitimacy and mistrust in extant hierarchical modes of governance. Complexity follows from the inherited organizational structure of the modern public sector, which historically emerged in the form of sectors for education, social services, social insurance, unemployment, health, old age, etc. This tendency toward sectorization is strengthened by latter-day introductions of management tools such as results-oriented management. While favorable from certain points of view, the emergence of strong sectors and so-called administrative 'silos' also creates deep-seated problems, making some coordinated and holistically optimal solutions more difficult in operative governance. There are some ironies in this: solutions to problems give rise to problems that must be solved. Complexity necessitates coordination across formal government structures and jurisdictions, as well as across public and private spheres of society (Kaufmann et al., 1986; O'Toole et al., 1997) in order to generate implementation capacity, or mobilize the 'power to' (Stone, 1993).

More specifically, the need for horizontal coordination is seen as the result of two interrelated types of complexity in public sector governance (cf. Koppenjan and Klijn, 2004: 6). Substantive complexity concerns the subject matter under consideration - i.e. housing segregation, social exclusion, homelessness, regional growth, or sustainable development. When understood as complex, the substantive policy problem is caused by a large number of factors interacting in intricate ways. In such a situation, we should expect uncertainty and disagreement, not only about an appropriate description of the problem, i.e. its nature, causes, and consequences, but also its solutions. The literature refers to such complexity as wicked problems (Koppenjan and Klijn, 2004: 6) or ill-structured problems (Simon, 1962).

Coordination among various actors and stakeholders then becomes an important tool for bringing together different perspectives, skills and resources to develop and refine problem definitions and policy theories. From such a starting point, the aim of network governance is to organize a kind of workshop in which different experiences and perspectives are presented and discussed in order to generate new and more holistic understandings of the problem and comprehensive solutions to it. Coordination resolves complexity by bringing in innovative and pioneering ways to understand and address the substantive problem.

Even if the substantive complexity can be clarified, grasped or even reduced, from a management perspective complexity may still prevail. The refined problem image may touch tangentially upon several established public agencies with different goals, objectives, and jurisdictions: it stretches across them (Hertting, 2003: 127; Koppenjan and Klijn, 2004; O'Toole et al., 1997). One manifestation of such institutional complexity is the talk about 'silos'. Silos refer to vertical structures that are organized to process major problems but that are unable to cope with some broader and intractable problems whose causes are many and controversial and whose solutions are highly dependent on the efforts of many actors. Those who talk about silos usually call for networking and cooperative structures in the form of networks, i.e. horizontal relationships between agencies, programmes and sectors. This is not a matter of the complexity of problems in a substantive sense. The complexity resides in the fragmented structure of the potentially relevant remedial organizational machinery (cf. Hjern, 1992). 


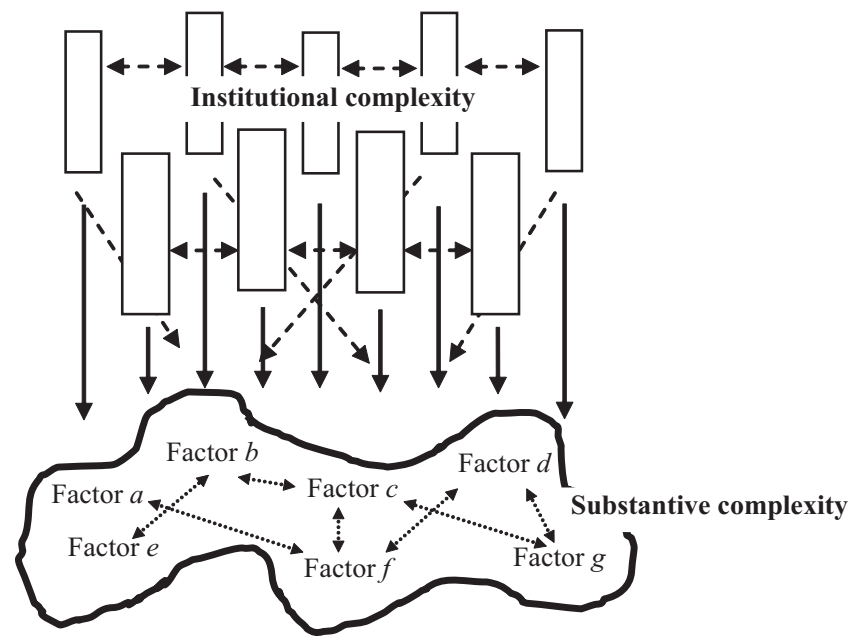

Figure I. Institutional and substantive complexity

Moreover, it should be noted that, in the end, complexity due to institutional diversity (such as partitioning into budget areas, policy sectors, or agency jurisdictions) is a matter of political priorities, previous or contemporary. Much as some important problems concern several of these institutions and may end up being neglected because they fall between all of them, the fundamental institutional structures are kept because they are regarded as instrumental in addressing more important policy tasks, with a higher political priority. That is, some issues turn into complexity because certain institutional changes are not prioritized - be it due to vested interests, popular will or blame avoidance.

\section{The governance solution, part I: Interdependencies and informal self-organization}

According to our ideal-type doctrine, network governance is rationalized and justified as a response to problems with substantive, institutional and political dimensions of complexity in public policy. Through its emphasis on coordination, network governance promises to turn complexity into holistic synergies, without formally intervening in established and politically important structures. The 'magic' of network governance is that its problem is also its solution. In the minds of central actors driven by the network governance doctrine, complexity is not only a problem but also provides an opportunity and institutional solution (Carlsson, 1993; Hertting, 2003). Complexity - now conceptualized in terms of interdependencies (Rhodes, 1997; Scharpf, 1978) - is regarded as a potential driver toward enhanced voluntary, horizontal coordination. According to this train of thought, when the complexity of problem-solving increases, vertical governance will be insufficient, while on the other hand, complexity will form the basis for new, horizontal forms of governance and coordination (Kaufmann et al., 1986; Ostrom, 1985 [1973]).

'Networks develop and exist because of the interdependency between actors' (Klijn, 1997: 31). That is, in our terminology, a governance network is not just any set of interdependent actors. Nor is it any set of cooperating actors. It is a set of actors who have organized a cooperative network to handle their interdependencies (Hertting, 2007). Agencies entrusted with policy mandates to implement environmental policy, or to solve the homelessness issue or mitigate socially negative effects of segregated housing, are dependent on other actors if they do not own the issue. Such 


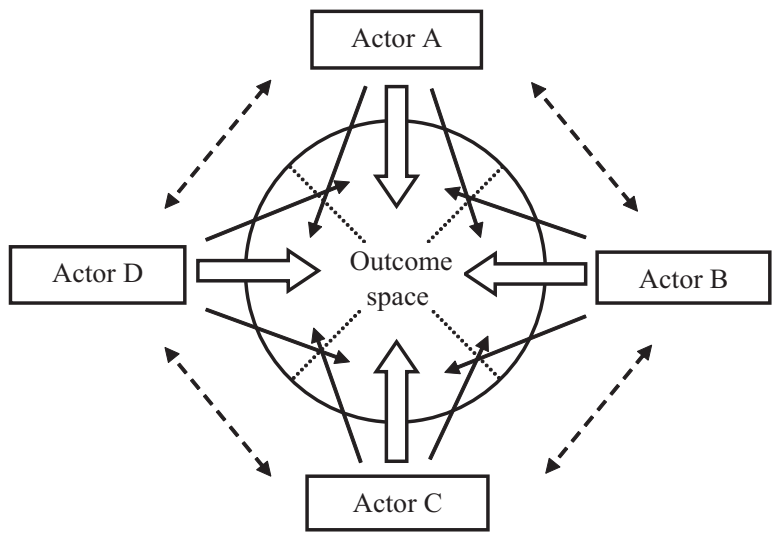

Figure 2. Shared outcome space, complexity and interdependencies

interdependent actors do not control their specific outcome space. They are not sovereign actors with the capacity to autonomously implement their agendas. As illustrated in Figure 2, the four authorities A, B, C and D do influence each other's results. In that sense, they are mutually interdependent. They do not control their own outcome domain.

In the situation pictured in Figure 2, it seems reasonable that the actors try to coordinate themselves. A central idea in network governance theory is consequently that interdependencies constitute incentives for operators to voluntarily coordinate their activities and strategies. Each operator is supposed to have incentives to spontaneously share resources, coordinate measures and frame common platforms with other actors - at least as long as the others do the same (Scharpf, 1994).

More specifically, we can identify several variants of this incentive to self-organization. The networking actors will for themselves and for their common weal incur an added value from cooperation by:

- pooling their resources into a common pot for a collective strategy;

- exchanging resources with each other for more optimal individual actions;

- adapting mutually in order to optimize individual strategies;

- collectively constructing new problem frames and frameworks for collective strategies.

Horizontal coordination follows from deliberation, open communication and mutual trust. At the same time, it may very well be a rational strategy for a single actor to hide or lie about her beliefs and preferences in order to create a better starting point for negotiations. That is, negotiations involve an intrinsic cooperation problem: if both actor A and B strategically manipulate the information about their preferences and capabilities, this will lead to imperfect negotiations and lack of coordination in the policy process. Having said this, it seems reasonable to expect that actors that repeatedly find themselves in this dilemma will value highly some kind of institutional framework (cf. Williamson, 1996). If the actors perceive interdependencies as quite stable and find a repeated need for negotiations, we should expect them to invest in institutions that make the single negotiation or deliberative activity more efficient. A fundamental idea of the network governance doctrine, then, is that we could expect networks that are capable of producing and coordinating efficient and legitimate policies and implementation to evolve endogenously among affected actors, without external top-down guidance or directives (Scharpf, 1994; cf. Hertting, 2007). 
In the literature, network governance is often described as informal structures. This informal character should not be mistaken for organizational failure. Informal organization is not lack of organization. The rationale behind network governance is its presumed ability to flexibly bring together organizations and sector actors with different goals and affiliations to different hierarchical systems for the purpose of framing strategies and taking action in individual cases. This is achieved because the relevant vertical organizational units get involved on the basis of their own organizational goals and assignments. Hence, the very informality of networks enables organizations to come together and create problem-solving collaboration without changing any fundamental lines of command and authority (cf. Chisholm, 1989). It is a feasible governance solution in situations where there is a need for coordination but where formal restructuring would be too demanding or politically cumbersome.

\section{The governance solution, part 2: Rationale and instruments for external network governance}

Informal organization, however, does not only have a distinct value from the horizontal perspective of self-organizing partners. We also argue that in order to understand the attractiveness of network modes of governance from a top-down perspective, we must use the rationale of informal organization as a clue. The informal character makes this type of governance preferable when the policy problem intermeshes with two or more extant and well-established policy sectors. In these circumstances, structural reorganization of the sectors may seem out of the question for administrative and economic reasons. In addition, political and administrative leaders may prefer network governance as an easy way out compared to shaking up long-established sectorial borderlines, thereby running the risk of provoking organizational resistance.

Hence, it is no contradiction in terms that external governors, such as a national government, or the European Commission, may play a central role in network cooperation and coordination as facilitators. According to our ideal-type definition, they may do so if their stimuli are intended and organized as starters, based on the idea that, in the long run, the pertinent actors themselves will cooperate and organize cooperation. They may do so by stimulating the creation and maintenance of networks from a distance, without participating in actual network labor (Pierre and Peters, 2000: 79). In the literature, such key initiatives to launch or boost network governance from the outside are sometimes referred to as 'meta-governance' (Sørensen and Torfing, 2007b). Here we prefer to talk about governance by an external facilitator or external network governance (Vedung, 2006: 23).

Such network-external governance strategies may work through hierarchical relations within the various network partners. The individual organizations within the network are often embedded in hierarchical relations. ${ }^{3}$ In order to stimulate network development, a government may therefore direct its own agencies to start cooperation with other public and private actors. If network governance collaboration is blocked by risk-averse and opportunistic strategies (Hertting, 2007: 52), such a hierarchical directive or admonition to one single actor may actually be sufficient to overcome the dilemma and start the emergence of cooperative norms and trust among participants (cf. Biancho and Bates, 1991). Hence an external facilitator may make a difference by activating a forerunner, a risk-absorber and a good exemplar (arrow A in Figure 3).

But external network governance may also be aimed at the network as such (arrow B in Figure 3), particularly the network of actors perceived as critical and productive from a top-down policy perspective, or according to a certain policy theory. ${ }^{4}$ Such strategies may aim to stimulate and vitalize an existing network, or encourage network formation and operation where no network exists (see Figure 3b). 

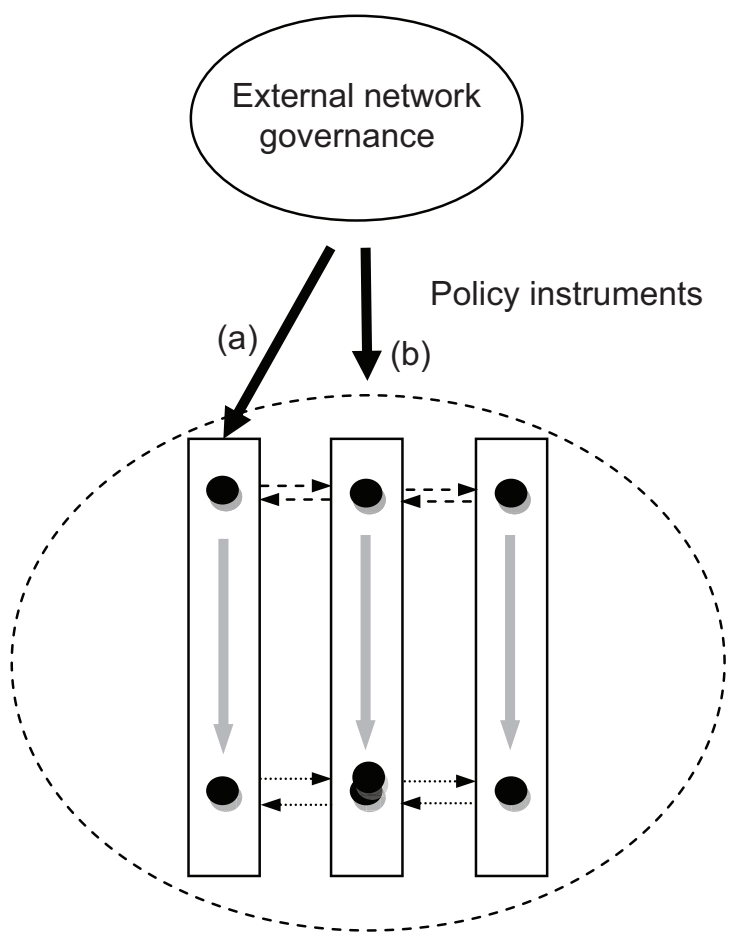

Figure 3. Actor focused (a) and network focused (b) external network governance

External network governance of this kind attempts to influence the conditions for horizontal collaboration between interdependent operational actors - based on the idea that they have incitements of their own to coordinate their actions. External governors can help and enable actors by allocating time-limited funds (Scharpf, 1978), creating venues for meetings between actors (Koppenjan and Klijn, 2004: 188) and launching comprehensive discursive frames as 'umbrellas' under which the actors in question can identify their dependent relationships with others (Klijn and Teisman, 1997: 105). In addition, an external governor may also assume a more direct role as a mediator or process leader - or, as the financial sponsor of such functions (O'Toole et al., 1997 - always without participating as a network partner.

Generally speaking, there are three and only three types of policy instruments (Vedung, 1998: 29) that an external governor may use to influence the formation and maintenance of network governance: economic, regulatory, and informative instruments, or carrots, sticks, and sermons for short. We argue that all three might be used by network-external actors to stimulate latent networks to take action and form real networking (cf. Bruijn and Heuvelhof, 1997). Hence, adding the three categories of policy instruments to the distinction between network partneroriented and network-as-a-whole-oriented strategies, the external facilitator may stimulate network governance in six different ways (Table 1).

\section{Network governance:A summary}

A governance doctrine specifies a logic whereby the use of certain policy instruments is linked to an idea about how they may solve a specific governance problem in a specific governance context. By drawing on several ideas and notions in the literature, it has been our ambition to delineate such 
Table I. Three basic types of policy instruments oriented toward two different features of network governance

\begin{tabular}{|c|c|c|c|}
\hline & Regulative & Economic & Informative \\
\hline $\begin{array}{l}\text { Single participating } \\
\text { actor (organization) } \\
\text { in the network }\end{array}$ & $\begin{array}{l}\text { Directives to cooperate } \\
\text { and work for the } \\
\text { establishment or } \\
\text { maintenance of network } \\
\text { relations with other } \\
\text { actors; organize and set } \\
\text { up new actors in order } \\
\text { to change the field of } \\
\text { interdependencies }\end{array}$ & $\begin{array}{l}\text { Material incentives } \\
\text { or disincentives to } \\
\text { mobilize, cooperate } \\
\text { and work for the } \\
\text { establishment or } \\
\text { maintenance of network } \\
\text { relations }\end{array}$ & $\begin{array}{l}\text { Suggestions (admonitions) } \\
\text { to establish or maintain } \\
\text { network governance with } \\
\text { other actors }\end{array}$ \\
\hline $\begin{array}{l}\text { Whole network of } \\
\text { actors }\end{array}$ & $\begin{array}{l}\text { Regulation of formal } \\
\text { collaborative procedures } \\
\text { that eventually may } \\
\text { develop into broader } \\
\text { understanding of } \\
\text { interdependencies and } \\
\text { long-lasting network } \\
\text { relations }\end{array}$ & $\begin{array}{l}\text { Economic incentives } \\
\text { to start collaboration } \\
\text { projects, conferences } \\
\text { etc that may develop } \\
\text { into broader } \\
\text { understanding of } \\
\text { interdependencies and } \\
\text { long-lasting network } \\
\text { relations }\end{array}$ & $\begin{array}{l}\text { 'Framing' through } \\
\text { umbrella goals, sector } \\
\text { norms, etc., in order to } \\
\text { affect the understandings } \\
\text { of dependencies } \\
\text { and eventually the } \\
\text { development of network } \\
\text { relations }\end{array}$ \\
\hline
\end{tabular}

a doctrine and to grasp the rationale behind certain central governance practices - practices that look irrational or simply strange from the perspective of other doctrines (cf. Hertting and Vedung, 2009). Following the structure of the doctrine concept, we have tried to formulate why external governors aim for formation and maintenance of network governance, that is, what kinds of problems network governance is deemed to be a reasonable solution to.

It is now high time to delineate these ideas into a condensed ideal-type. Below, we sum up ideas about the problems and solutions found among holders of a network governance doctrine:

1. With reference to the substantive complexity characterizing some social problems and the institutional complexity of their potential remedial organizational machineries, policymakers regard horizontal coordination across programme, agency, sectoral and organizational boundaries and jurisdictions as an important problem of governance.

2. Such complexity creates interdependencies among operative actors and they are therefore assumed to have incentives to coordinate and cooperate for their own and thereby, indirectly, the common good.

3. Because network governance operates across formal hierarchies and authority borders in government and between the public and the private spheres, informal forms of coordination are regarded as appropriate and productive from the perspective of both network partners and external network facilitators.

4. Using any type of policy instrument, network-external actors stimulate and facilitate potential networking agents to launch and maintain network governance.

That is, when central policymakers and instigators of an intervention (a) with reference to substantive and institutional complexity regard lack of horizontal coordination as the most important governance problem, (b) assume that operational actors themselves actually have incentives to coordinate and cooperate for their own and thereby, indirectly, the common good, and (c) will do so informally, 
across formal hierarchies and authority borders in government and between public and the private spheres, (d) if stimulated by an external network governance facilitation initiative through any type of policy instrument, then we may talk about a pure network governance doctrine.

In the rest of the article, we will discuss the significance of some standard notions of evaluation theory for evaluation of network governance. What are the roles of the time-honored overarching evaluative purposes - development and accountability - in evaluation of network governance? What evaluative merit criteria should be used in network governance evaluation?

\section{The evaluation problem}

Evaluation in its everyday sense refers to the universal process of determining the merit, worth, and value of something - or the product of that process. It implies distinguishing the worthwhile from the pointless, the precious from the worthless. In present-day public sector management, however, evaluation has acquired more specific and narrow meanings. Here, evaluation is a mechanism for monitoring, systematizing, and grading ongoing or finished public sector interventions (organizations, policies, programmes, projects, activities, their effects, and the processes preceding these effects, perceptions of the content of the interventions included) so that public officials and stakeholders in their future-oriented work will be able to act reasonably.

In the present article, the following minimal definition of the term evaluation will be adopted:

Evaluation is the careful assessment of the merit, worth, and value of organization, content, administration, output, and effects of ongoing or finished government interventions, which is intended to play a role in future, practical action situations.

Our minimal definition is basically in line with standard notions of evaluation in relevant literature. On this account, we wish to be conventional, not original. Evaluation concerns government interventions. These are ongoing or finished but not on the drawing board. Evaluation is not concerned with effects only, but also with organization, content and the processes preceding effects. Evaluation is supposed to pass careful judgments on the evaluated, i.e. assessing their merit. Finally, evaluation is intended to have impacts on future action. Other notions of evaluation are carefully listed, referenced, and extensively discussed in, for example, Vedung (1997: 2-13; cf. e.g. Clarke, 1999: 1; Rossi and Freeman, 1985, 1989, 1999).

In what follows, we will use a set of standard notions from evaluation theory to discuss their relevance and meaning within the frame of the network governance doctrine. More specifically, we will discuss the notions of accountability and development as overall evaluation purposes, and the notions of goal-attainment and stakeholder evaluation to handle the merit criteria problem.

\section{Purposes of network governance evaluation}

The overall rationale of evaluation is to create repositories of descriptive and judgmental insights for reasoned practical thought and action. Under this practice-servicing umbrella, evaluation is usually performed for either development or accountability.

\section{Development and its variants - the normal purpose of network governance evaluation?}

Addressing problems that are substantively complex (substantive complexity) and run across established agency structures (institutional complexity) is the rationale of network governance. This doctrine is about creating new forms of collaboration and new problem images, objectives and 
practical actions from a more holistic perspective. For this reason, we may argue that development, not accountability, is the normal and central purpose of ideal-type network governance evaluation (cf. Koppenjan and Klijn, 2004: 125; Van der Meer and Edelenbos, 2006).

The development (improvement, learning, lesson-learning, promotion) perspective can be formative, aspiring to guide amendment of the evaluated intervention in terms of its implementation. It is felt that the ongoing intervention will continue its operations in the foreseeable future, but that it might be in need of improvement. Formative development is rooted in formative evaluation, according to which methods, strategies, and activities are questioned but not the goals to be achieved. Formative evaluation is a process of error detection within extant structural frames pursued in order to modify methods, strategies, and activities to better solve the task at hand. The idea is to achieve single-loop learning. Single-loop learning implies that the organization learns something about the functionality of the means, which is supposed to engender change in and amelioration of the means without changing the goals in the least.

The development perspective can also be summative. Not only does summative evaluation question the means, but also the intervention goals and even the framing of the underlying problem in order to learn something that might be used in launching similar but better interventions in the future. Summative evaluation prepares for double-loop learning. The whole intervention - with problems, goals, means, activities and strategies - is studied and questioned. The summative purpose is more grandiose and comprehensive than that of formative evaluation. It also aims at the improvement of future interventions, not only the one currently being evaluated.

One worthy aspiration of general evaluation, development, has a role to play in network governance evaluation as well. Yet that role will be different. At the level of the network as a whole, development evaluation implies joint learning among all participating agencies and organizations of the network, not primarily the learning of each individual agency or organization. In focus is the participants' understanding and learning of their common problem images, goals, resource ownerships and dependency relationships.

In fact, we argue that this type of development evaluation, for the purpose of establishing and refining a common mindset concerning the substantive issue as well as the roles and responsibilities of the participating agencies and organizations, is very central to network governance. Findings from evaluation of previous processes will then be a basis for ongoing dialogues about how various activities should be aligned and organized in relation to each other. The evaluation becomes a tool for enlightenment and probing as much as for finding solutions.

Although we believe this inter-organizational and cross-sectoral development perspective is central in governance by networks, it does not mean there are no others. There is a second development perspective as well. As part of each parent organization, it is reasonable that development evaluation be very much about supporting learning in relation to the individual organization's own goals for participating in the present network (formative development) or in some future network effort of the same kind (summative development). And it is by no means obvious that the parent organization's perspective will coincide with the total network's perspective.

Hence, there are many development perspectives to be considered in evaluating network governance. The network evaluator therefore needs a strategy to handle them, one by one or taken together in a comprehensive assessment - a conclusion that is even more relevant when we now turn to the issue of accountability evaluation in network governance.

\section{Four types of accountability purposes in network governance}

The accountability issue is the Achilles heel of network governance. Allowing public agencies and civil society organizations to form horizontal networks across sectors, programmes and 
jurisdictions to develop common problem images, objectives and action plans may be a reasonable governance strategy. But who is responsible for what in such horizontal networks among equals? What does accountability mean within the network governance doctrine? How is democratic accountability to be upheld?

Traditionally, accountability is understood in hierarchical terms (Pollitt, 2003: 89; Scharpf, 1997: 183). Accountability should be executed through a vertical chain of relationships between superiors and their subordinates. Those superiors (principals) who have delegated responsibilities to their subordinates (agents) should subsequently check that their subordinates (agents) have lived up to these responsibilities and if so, either discharge or advance criticism and take action. The key rationale of accountability evaluation is to find out how agents have exercised their delegated powers so that principals can judge their work and take appropriate action. Accountability evaluation is a tool for superiors to check their subordinates and to hold them and the intervention responsible for their actions.

The first dimension of accountability is reporting in which descriptions are provided. A second function is a justifying analysis or explanation. In instances where a justifying analysis recognizes deficiencies, true accountability requires a third dimension: answerability - that is, those in charge must be held responsible.

But what about accountability evaluation in horizontal networks where all parties are equal and no party is superior to the others? Is it at all relevant to maintain that anyone has any responsibility to somebody else in horizontal networks? We believe so. Below we will outline four different accountability perspectives in network governance.

A principled governance network consists of a set of interdependent parties self-organized into horizontal relationships for attacking a problem. Within the network, the parties have a responsibility to each other (Rhodes, 1997). For the functioning and results of their networking they carry joint responsibility (Koppenjan and Klijn, 2004). This first accountability perspective is focused on horizontal cooperation as such, and the danger that collaboration problems may arise among the networking parties. An accountability perspective, that is, may be present also in perfect horizontal relationships: as a matter of the participating networking partners' responsibility for and control of each other. Are agreements and informal norms complied with? As Elinor Ostrom has shown in Governing the Commons (1990: 204), an important prerequisite for successful cooperation is that the cooperating partners themselves jointly organize mutual monitoring of each other. The mere presence of a monitoring system can be beneficial without it being activated. It may work through its shadow, through anticipation. Is cooperation reciprocated by cooperation, or are some network partners acting as free-riders? To what extent do the stakeholders honestly and genuinely cooperate with each other? How often and how long do the partners meet each other in the network? How well are the participating organizations represented? Do their representatives have sufficient knowledge and sufficient mandates from their respective parent organizations for the network to operate properly? Are the participants well prepared for discussions and meetings (Hertting, 2007: 51; Vedung, 2006: 42)?

However, albeit not primary, there are vertical accountability relationships in network governance. Each networking parent organization is a principal with motives to control her agents representing it in face-to-face collaboration processes (cf. Vedung, 2006: 20). Then networking is regarded as an asset to and an instrument for each agency and organization. Is the agent a good representative of my interests in the operative collaboration processes? This is the second accountability perspective.

In fact, the accountability problem in network governance is rather delicate and multifaceted. On the one hand, network management is fundamentally based on the parties' own initiatives to coordinate resources and activities. On the other hand, network governance is legitimated by its 


\begin{tabular}{c|l|l|}
\multicolumn{2}{c}{ Internal } & \multicolumn{1}{c}{ External } \\
\cline { 2 - 3 } Horizontal & $\begin{array}{l}\text { 1) Mutual accountability } \\
\text { among network } \\
\text { partners }\end{array}$ & $\begin{array}{l}\text { 3) Accountability of } \\
\text { network (partners) to } \\
\text { constituencies }\end{array}$ \\
\cline { 2 - 3 } Vertical & $\begin{array}{l}\text { 2) Accountability within } \\
\text { network partner: } \\
\text { 'mother organization'- } \\
\text { network representative }\end{array}$ & $\begin{array}{l}\text { 4)Accountabilityof } \\
\text { network (partners) to } \\
\text { external governor }\end{array}$ \\
\hline
\end{tabular}

Figure 4. Four accountability perspectives in network governance

effectiveness, efficiency, innovative power and ability to solve broad social problems, which are not and cannot be bounded to each participating organization's mandate and activities. The key is not that network actions reflect each parent organization's individual goals, but that the common outcome for society - the collective good, as it were - is better than if the network parties, instead of networking, were to realize their respective goals separately (Scharpf, 1997: 153, 189).

This last observation raises the third accountability perspective in network governance. It is about the networking parties' shared responsibility to relevant outsider stakeholders who are not members of the network at all. Does the network as an organized activity really resolve their problems? This accountability perspective can be formulated in terms of responsivity (see Papadopolus, 2003: 482f). The issue is not whether the network has acted within the limits of its prior mandate, but whether those who are not among the networking players and are affected and concerned experience ex post that the network has been effective in realizing their wishes. This is accountability in the light of a very controversial idea of government for the people rather than by the people (cf. Scharpf, 1997).

A fourth accountability perspective arises in the case where an external network governor such as the State, the European Commission, or the Municipality intervenes to promote network governance, e.g. through financial incentives. Have the external funds been used properly and in the manner intended? Has a coordination process been satisfactorily established?

In sum, we have identified four accountability perspectives, which will arise in the evaluation of interventions designed according to the network governance doctrine. As illustrated in Figure 4, the four accountability perspectives can be defined along two dimensions. Do they refer to relations among insiders within the network or between actors inside and outside the network? And to what extent are the relations horizontal (reciprocal) or vertical (hierarchical)? Both parent organizations and their representatives doing practical networking are regarded as insiders, whereas every actor external to these two are regarded as outsiders.

\section{Merit criteria in network governance evaluation}

So far we have discussed what development and accountability, as overall purposes, might mean in evaluation of initiatives fashioned according to the network governance doctrine. Accountability is not irrelevant as a purpose in such evaluation endeavors. On the contrary, it is relevant from several different perspectives. Next we need to define what would count as development and what would count as accountability. In order to address these issues, it is necessary to clarify also the evaluative merit criteria to be used in network governance evaluation. If a network is responsive to client groups (targets) rather than its plurality of principals, is that good or bad? If it is successful 
in generating new perceptions and ideas about the problem being attacked but not able to move on to operative actions, how do we judge such a network?

A key process in public sector evaluation is to determine the merit, worth or quality of the public intervention under appraisal. This necessitates the use of evaluative merit criteria. Evaluative criteria may be determined in the planning of the evaluation (ex ante), during the process of conducting the evaluation (ex nunc) or after the evaluation is finished (ex post). Furthermore, criteria can be descriptive or prescriptive. In descriptive valuing, the evaluator chooses the values of others as evaluative criteria and standards. In prescriptive valuing, the evaluator herself advocates the primacy of particular values, such as justice, equality and client needs, regardless of whether these values are adopted by any decision-making body or embraced by some stakeholding constituency.

\section{Is the goal-achievement criterion really irrelevant?}

Using goal attainment as an evaluative criterion is worthless, if not outright fallacious. This is a common verdict in the literature (Carlsson, 2000; Kickert et al., 1997: 172; Koppenjan and Klijn, 2004: 124; Van der Meer and Edelenbos, 2006). We both agree and disagree. Ideal-type network governance is self-organized by equal partners and horizontal in its structure. There is no joint governor of the network as a whole. Ex ante, therefore, there is no common goal for all participating actors (Vedung, 2006: 52). However, common perceptions, frameworks, visions or even goals for the whole network may emerge as products of networking processes. Within a network, such common formulations developed during the course of network operations could be used as yardsticks to assess whether the individual network partners have contributed to the achievement of these goals.

Also at the level of each individual network partner, it is often assumed that all of them individually learn and develop new objectives and aims (Kickert and Klijn, 2004). Individual goals are searched for and framed. However, this does not mean that the ex ante objectives of the networking partners are irrelevant. If network governance arrangements are developed to handle interdependencies between different partners, it seems indeed reasonable to evaluate these arrangements according to their institutional capacity to increase the implementation capacity of the each participating partner. From a network governance point of view, network governance is driven by the partners' desires to mobilize resources and reduce uncertainty in order to improve their ability to realize their respective goals (cf. Hertting, 2003: 49). From such a perspective, achievement of ex ante goals becomes relevant, though within a network governance doctrine there is not one set of goals only but several sets of ex ante formulated goals to use as yardsticks. Thus, it seems reasonable to evaluate also in relation to the ex-ante goals of each individual participant.

Finally, it might be relevant to evaluate goal achievement from the perspective of an external network facilitator. In this case, goal-achievement seems relevant as a yardstick for assessing processes (Vedung, 1997). Without participating in ensuing actual network labor, the aim of the external facilitator is to stimulate latent partners to launch and maintain problem-solving through cooperative networking. Yet the aim is also that these developed processes and procedures contribute to the attainment of the umbrella goals set by the facilitator. From such a perspective, the broad umbrella goals formulated by external facilitators in their intervention should be evaluated according to both their mobilizing capacity and their ability - thanks to this mobilizing - to further the achievement of the umbrella goals (cf. Hertting and Vedung, 2009).

\section{Holistic network evaluation and the many meanings of the stakeholder approach}

Network governance promises holistic and coordinated solutions to social problems. A standard evaluation response to handling complexity and holistic judgements is stakeholder evaluation 
(Guba and Lincoln, 1989). Hence, while goal-achievement has been discarded by evaluation pundits as inappropriate in network governance evaluation, the stakeholder model is often seen as the obvious solution (De Bruijn and Ringeling, 1997; Koppenjan and Klijn, 2004: 128; cf. Vedung, 2006). A palpable similarity is that stakeholder evaluation, like the network governance doctrine, takes pluralism in terms of values as its starting point and often stresses the importance of deliberative process in order to assess holistic values (Hajer and Wagenaar, 2003). Yet what is it that the stakeholder approach to holistic evaluation might offer the doctrine of network governance?

The fundamental idea of stakeholder evaluation is that the claims, concerns and issues of the various affected actors should serve as points of departure when interventions - their processes, outputs and outcomes - are assessed and evaluated (Vedung, 1998). The evaluation should be set up with significant stake-holding audiences represented or taken into consideration. Stakeholder approaches to evaluation typically also emphasize the significance of discussion, dialogue, and communication among those affected by or with a stake in a programme or project, even deliberation avant la lettre (see e.g. Guba and Lincoln, 1989: 56):

The involvement of stakeholders ... implies more than simply identifying them and finding out what their claims, concerns and issues are. Each group is required to confront and take account of the inputs from other groups. It is not mandated that they accept the opinions and judgments of others, of course, but it is required that they deal with points of difference or conflict, either reconstructing their own constructions sufficiently to accommodate the differences or devising meaningful arguments for why the others' propositions should not be entertained.

In order to specify how the stakeholder approach may respond to the network governance doctrine, two different claims should be separated here. One aspect is whether stakeholders are supposed to judge the intervention from an individualistic or a holistic perspective; another whether they need to deliberate among themselves in order to complete such a judgement. By taking both dimensions into account, we will also be able to identify a non-deliberative and non-holistic type of stakeholder evaluation (Figure 5).

Deliberative dialogues intended to produce or construct collective understandings and assessments are crucial within network governance. Such dialogues might create new understandings of current interdependencies as well as collective frameworks for providing productive interactions and negotiations in the future. From such a perspective, stakeholder evaluation could be regarded an integrated part of the network governance process as such. After all, the crucial governance problem of the network doctrine has to do with the search for synergies and coordination.

Such deliberative discussions among network partners and stakeholders may facilitate evaluation in two respects. First, they may produce substantive network goals, process rules or even programme theories to be applied as merit criteria by the evaluator (cf. the above discussion on emergent goals as criteria). More true to standard stakeholder evaluation thinking, however, such deliberative processes may also produce collective and holistic assessments as such. With dialogue and discussion as the very heart of the stakeholder approach, evaluators and stakeholders jointly produce a collective understanding and consensual valuing of the programme or project (Fischer, 2003: 137; Guba and Lincoln, 1989: 69). However, such a stakeholder evaluation model need not, we argue, bring in 'social constructivism' - at least not in its 'thick' version (Hay, 2002: 206). There is an argument for deliberation being crucial to holistic assessments without taking a strong social constructivist position. Dialogues among stakeholders need not be about constructing the world of programmes and outcomes, but about negotiations on what stakes and priorities are most important, and hence what is the preferred state when every position is taken into account.

In the contemporary literature on deliberative democracy, the case for deliberation is not only made from a holistic or collective perspective. It is not only a matter of creating shared 


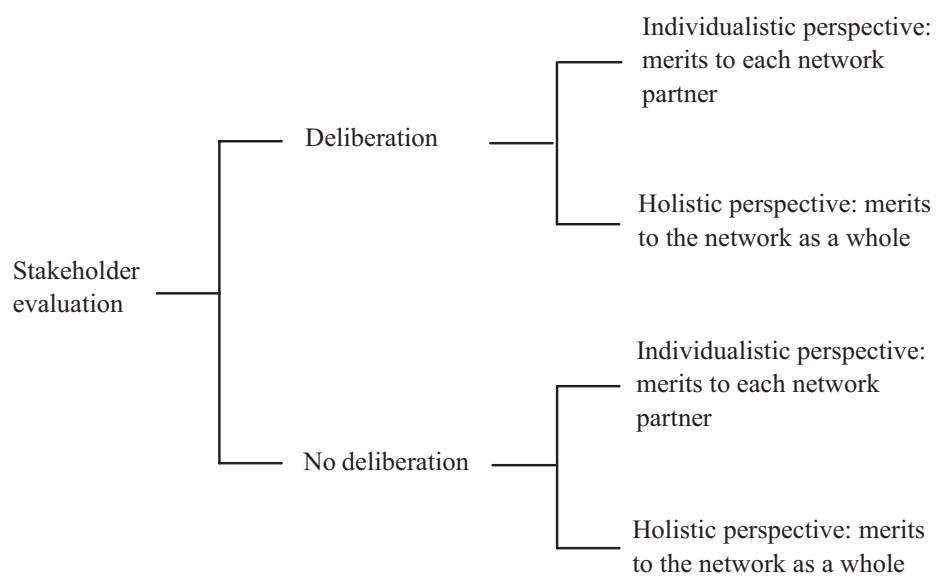

Figure 5. Stakeholder evaluation

understandings and values. Individuals also need deliberation to clarify and refine their own individual preferences (Elster, 1998; Goodin, 2003). Using a similar argument, we claim that deliberation is a crucial aspect of stakeholder evaluation in two different ways (Figure 5).

Following such an argument, a deliberative approach to network governance evaluation might be of value even though the final assessment is made from the perspective of each singular network partner or stakeholder in a wider sense. Each actor evaluates whether the network and its results, in terms of processes, produced framings and policies, operative actions and outcomes, have been satisfactory from their individual perspective. Hence deliberation may be productive without generating holistic understandings or judgments per se.

Following Hansen and Vedung (2010), we argue that there is room for a less unified and more segregated stakeholder approach. Especially in complex intervention situations, where the network governance doctrine seems most productive, it seems reasonable to present such a holistic but not integrated picture of assessments. Sometimes, we would argue, it may even be wise to avoid deliberation among participants and stakeholders. Where argumentative resources are unequally distributed, legitimate and important conflicts may disappear from the evaluation agenda. In such situations, it may be relevant to collect assessments from each stakeholder, and produce a holistic picture of how every stakeholder evaluates the network interactions, processes, policies and/or outcomes, without prior deliberation. ${ }^{5}$

Hence, without necessarily taking onboard a social constructivist position, the stakeholder evaluation model provides at least four different approaches to assessing interventions characterized by the network governance doctrine. They are summarized in Figure 5 below:

\section{Conclusions}

How can public sector interventions guided by a network governance doctrine be evaluated? Are core concepts of standard evaluation theory universal enough to also be faithfully applied to network governance? These questions capture the main thrust of the present article.

Here, we have tried to distill the notion of a network governance doctrine in public policy. We have done so by outlining an ideal-type governance doctrine characterized by four features. That is, when central policymakers and instigators of an intervention (a) with reference to substantive 
and institutional complexity regard lack of coordination as the most important governance problem, (b) assume that operational actors themselves actually have incentives to coordinate and cooperate for their own and thereby, indirectly, the common good, and (c) will do so informally, across formal hierarchies and authority borders in government and between the public and private spheres, (d) if stimulated by an external network governance facilitation initiative through any type of policy instrument, then we may talk about a pure network governance doctrine.

As such, of course, it will rarely appear in the real world. Real-world governance doctrines are much more complicated and detailed. However, based on such a delineated ideal-type, we pose the question of evaluation in network governance. How should we go about evaluating network governance-like doctrines? Are traditional notions such as accountability as one overall evaluative purpose or the goal-achievement criterion at all relevant in evaluating network governance?

Though it takes some elaboration, our overall conclusion is that at least some standard evaluation concepts and approaches are still productive in delineating, analysing and prescribing how network governance can be evaluated. In the article, we have tried to contribute to such an elaboration and adjustment. More specifically, we have stressed that the current body of literature has neglected - or been too pessimistic about - the accountability issue in network governance. We offer four different accountability perspectives to be used in network governance evaluation.

In a similar fashion, we disagree with claims made in the literature about the irrelevance of goal attainment as an evaluative criterion; we do this for three reasons. First, common network goals may emerge as products of the network process and be used as yardsticks to assess whether the individual network partners have contributed to their achievement. Second, achievement of each individual participant's ex ante goals is perfectly legitimate as criteria in network evaluations. Third, it might be relevant to talk about goal achievement from the perspective of an external network facilitator, whose aim it is to induce the acceptance of umbrella goals and more coordination to reduce complexity and eventually organize innovative problem-solving (cf. Hertting and Vedung, 2009).

Finally we argue that, though stakeholder evaluation could be regarded as the 'obvious solution' to a holistic evaluation of network governance, it is still quite ambiguous. By making a distinction between the existence of deliberative processes and the perspective of judgment within stakeholder evaluation, we identify four different categories. Sometimes, we argue, it may be reasonable to avoid deliberation and aim for a less unitary stakeholder approach in appraising network governance-like interventions.

\section{Acknowledgement}

Valuable comments were provided by three anonymous reviewers for this journal and by Hanne Foss Hansen and other scholars at the Nordic Political Science Association Vaasa workshop on evaluation in August 2011. The IBF, Uppsala University, defrayed the costs of Vedung's participation in the conference. While entirely new, the article partly draws upon ideas in our book Den utvärderingstäta politiken, supported financially by the Research and Development Council of the Swedish Association of Local Authorities and Regions.

\section{Funding}

This research received no specific grant from any funding agency in the public, commercial or not-for-profit sectors (see Acknowledgement above).

\section{Notes}

1. Cf. Hood and Jackson (1991: 468) who invoke Andrew Dunsire's not very transparent definition (1993: 39) of doctrine as 'a set of ideas that lies half-way between "theory" and "policy" - where theory means an attempt to explain some part of the environment, so as to make any observations about it consistent 
with one another, with the sole purpose of approaching "truth" or understanding, and "policy" designed to initiate and guide actions in it so as to make all actions consistent'.

2. The Weberian notion of an ideal-type is not an ideal in the sense of something perfect or supremely excellent; something normatively valuable. Furthermore, ideal-types are not meant to provide an empirical description or to portray something. Nor should ideal-types be understood as descriptive hypotheses. Quite contrary, the analytical and methodological value of ideal-types comes with their pure and delineated character, which normally renders them quite unrealistic. Hence, an ideal-type is a device, an intellectual utensil, to be employed in research. It is a methodological tool or a scientific or scholarly instrument by which researchers perform analyses.

3. Hertting $(2007,2009)$ even claims that hierarchical relations within the networking organizations may actually facilitate the horizontal games of network governance, by decreasing internal complexity and increasing visibility and understanding of the strategic field.

4. Fritz Scharpf once referred to this as the 'prescriptive' as opposed to the 'descriptive' network (Scharpf, 1978).

5. It is beyond the scope of the article to discuss external or endogenous merit criteria. However, information about individual stakeholder assessments may be aggregated to a holistic judgment by applying the entirely external coordination criterion (Lindblom, 1965: 24). If coordination is a state or situation in which actors have jointly considered and adjusted their decisions and actions to each other so that the whole is better for everyone as compared to the situation in which each partner acted alone (Koppenjan and Klijn, 2004: 125; Scharpf, 1994: 18), the question is whether the network governance intervention has improved the degree of coordination. Thus, the coordination concept provides a criterion that takes the individualistic assessments - after deliberation or not - as its input, but produces an assessment in collective or holistic terms.

\section{References}

Bianco W and Bates R (1991) Cooperation by design: leadership, structure, and collective dilemmas. American Political Science Review 84(1): 133-47.

Carlsson L (1993) Samhällets oregerlighet: Organisering och policyproduktion i näringspolitiken. Stockholm: Symposium Graduale.

Carlsson L (2000) Non-hierarchical evaluation of policy. Evaluation 6(2): 201-16.

Chisholm D (1989) Coordination without Hierarchy: Informal Structures in Multiorganizational Systems. Berkeley, CA: University of California Press.

Clarke A (1999) Evaluation Research: An Introduction to Principles, Methods and Practice, London: SAGE.

De Bruijn JA and Ringeling AB (1997) Normative notes: perspectives on networks. In: Kickert WJM, Klijn E-H and Koppenjan JFM (eds) Managing Complex Networks: Strategies for The Public Sector. Thousand Oaks, CA: SAGE, 35-61.

De Bruijn JA and Ten Heuvelhof EF (1997) Instruments for network management. In: Kickert, WJM, Klijn E-H and Koppenjan JFM, Managing Complex Networks: Strategies for the Public Sector. Thousand Oaks, CA: SAGE, 119-126.

Dunsire A (1993) Modes of governance. In: Kooiman J (ed.) Modern Governance: New Government-Society Interactions. London: SAGE.

Elster J (1998) Introduction. In: Elster J (ed.) Deliberative Democracy. Cambridge: Cambridge University Press.

Fischer F (2003) Beyond empiricism: policy analysis as deliberative practice. In: Hajer MA and Wagenaar H (eds) Deliberative Policy Analysis. Understanding Governance in the Network Society. Cambridge: Cambridge University Press.

Foss Hansen H (2003) Evaluering i staten: Kontrol, laering eller forandring. Frederiksberg: Samfundslitteratur. Goodin RE (2003) Reflective Democracy. Oxford: Oxford University Press.

Guba EG and Lincoln YS (1989) Fourth Generation Evaluation. Newbury Park, CA: SAGE.

Hajer MA and Wagenaar H (eds) (2003) Deliberative Policy Analysis. Understanding Governance in the Network Society. Cambridge: Cambridge University Press. 
Hansen MB and Vedung E (2010) Theory-based stakeholder evaluation. American Journal of Evaluation 31(3): 295-313.

Hay C (2002) Political Analysis: A Critical Introduction. London: Palgrave/MacMillan.

Haynes P (2008) Complexity theory and evaluation in public management. Public Management Review 10(3): 401-19.

Hertting N (2003) Samverkan på spel: Rationalitet och frustration i nätverksstyrning och svensk stadsdelsförnyelse. Stockholm: Égalité.

Hertting N (2007) Governance network formation. A contextual rational choice perspective. In: Sørensen E and Torfing J (eds) Theories of Democratic Network Governance. London: Palgrave-MacMillan, 43-60.

Hertting N (2009) Neighborhood network governance, ethnic organization, and the prospects for political integration. Journal of Housing and the Built Environment 24(1): 127-45.

Hertting N and Vedung E (2009) Den utvärderingstäta politiken: Styrning och utvärdering i svensk storstadspolitik. Lund: Studentlitteratur.

Hjern B (1992) Illegitimate democracy: a case for multiorganizational policy analysis. Policy Currents 2: $1-5$.

Hood C and Jackson M (1991) Administrative Argument. London: Gower.

Kaufmann F-X, Majone G and Ostrom V (eds), with assistance of Wirth W (1986) Guidance, Control, and Evaluation in the Public Sector: The Bielefeld Interdisciplinary Project. Berlin: W. de Gruyter.

Kickert WJM, Klijn E-H and Koppenjan JFM (eds) (1997) Managing Complex Networks: Strategies for the Public Sector. Thousand Oaks, CA: SAGE.

Klijn E-H (1997) Policy networks: An overview. In: Kickert, WJM, Klijn E-H and Koppenjan JFM, Managing Complex Networks: Strategies for the Public Sector. Thousand Oaks, CA: SAGE, 14-34

Klijn E-H and Edelenbos J (2007) Meta-governance as network management. In: Sørensen E and Torfing J (eds) Theories of Democratic Network Governance. London: Palgrave-MacMillan, 199-214.

Klijn E-H and Teisman GR (1997) Strategies and games in networks. In: Kickert WJM, Klijn E-H and Koppenjan JFM (eds) Managing Complex Networks: Strategies for The Public Sector. Thousand Oaks, CA: SAGE, 98-118.

Koppenjan JFM and Klijn E-H (2004) Managing Uncertainties in Networks: A Network Approach to Problem Solving and Decision Making. London: Routledge.

Lindblom C (1965) The Intelligence of Democracy: Decision Making Through Mutual Adjustment. New York: Free Press.

Ostrom E (1985 [1973]) The Intellectual Crisis in American Public Administration. Tuscaloosa: University of Alabama Press.

Ostrom E (1990) Governing the Commons: The Evolution of Institutions for Collective Action. Cambridge: Cambridge University Press.

O'Toole LJ Jr, Hanf KI and Hupe PL (1997) Managing implementation processes in networks. In: Kickert WJM, Klijn E-H and Koppenjan JFM (eds) Managing Complex Networks: Strategies for The Public Sector. Thousand Oaks, CA: SAGE, 137-51.

Papadopolus Y (2003) Cooperative forms of governance: problems of democratic accountability in complex environments. European Journal of Political Research 42: 473-501.

Pierre J and Peters GB (eds) (2000) Governance, Politics, and the State. New York: St. Martin's Press.

Pollitt C (2003) The Essential Public Manager. Maidenhead: Open University Press.

Provan KG and Kenis P (2007) Modes of network governance: structure, management, and effectiveness. Journal of Public Administration \& Theory 18: 229-52.

Provan KG and Milward HB (2001) Do networks really work? A framework for evaluating public-sector organizational networks. Public Administration Review 61(4): 479-516.

Rhodes RAW (1997) Understanding Governance: Policy Networks, Governance, Reflexivity, and Accountability. Buckingham: Open University Press.

Rossi PH, Freeman HE (and Lipsey MW) (1985) Evaluation: A Systematic Approach (3rd Edition). London: SAGE.

Rossi PH, Freeman HE (and Lipsey MW) (1989) Evaluation: A Systematic Approach (4th Edition). London: SAGE. 
Rossi PH, Freeman HE (and Lipsey MW) (1999) Evaluation: A Systematic Approach (6th Edition). London: SAGE.

Sanderson I (2001) Evaluation in complex policy systems. Evaluation 6(4): 433-54.

Scharpf FW (1978) Interorganizational policy studies: issues, concepts and perspectives. In: Hanf K and Scharpf FW (eds) Interorganizational Policy Making. Beverly Hills, CA: SAGE, 345-70.

Scharpf FW (1994) Games real actors could play: positive and negative coordination in embedded negotiations. Journal of Theoretical Politics 6(1): 27-53.

Scharpf FW (1997) Games Real Actors Play: Actor-Centered Institutionalism in Policy Research. Boulder, CO: Westview Press.

Simon HA (1962) The architecture of complexity. Proceedings of the American Philosophical Society 106: 467-82.

Sørensen E and Torfing J (eds) (2007a) Theories of Democratic Network Governance. London: PalgraveMacMillan.

Sørensen E and Torfing J (2007b) Theoretical approaches to metagovernance. In: Sørensen E and Torfing J (eds) Theories of Democratic Network Governance. London: Palgrave-MacMillan.

Uusikylä P and Valovirta V (2007) Three spheres of performance governance: spanning the boundaries from single-organization focus towards a partnership network. Evaluation 13(4): 399-419.

Van der Meer F-B and Edelenbos J (2006) Evaluation in multi-actor policy processes: accountability, learning and co-operation. Evaluation 12(2): 201-18.

Vedung E (1997) Public Policy and Program Evaluation, New Brunswick, NJ: Transaction.

Vedung E (1998) Policy instruments: typologies and theories. In: Bemelmans-Videc M-L, Rist RC and Vedung E (eds) Carrots, Sticks, and Sermons: Policy Instruments and Their Evaluation. New Brunswick, New Jersey and London: Transaction, 21-58.

Vedung E (2006) Konsten att utvärdera nätverk [The Art of Evaluating Networks]. Helsinki: Stakes.

Williamson OE (1996) The Mechanisms of Governance. Oxford: Oxford University Press.

Evert Vedung (Emeritus Professor)'s works on evaluation include Public Policy and Program Evaluation (Transaction) and 'Four waves of evaluation diffusion' (in Evaluation) and Carrots, Sticks and Sermons (coeditor). Please address correspondence to: Uppsala University, IBF, PO Box 785, SE-80129 Gävle, Sweden. [email: evert.vedung@ibf.uu.se]

Nils Hertting is Associate Professor in political science at the Institute for Housing and Urban Research and the Department of Government at Uppsala University. 